\title{
Eggs and larvae of anchoveta Engraulis ringens off northern Chile during the 1997-1998 El Niño event
}

\author{
Huevos y larvas de la anchoveta Engraulis ringens en el norte de Chile \\ durante el evento El Niño 1997-1998 \\ Pablo M. Rojasis ${ }^{1}$ Mauricio F. Landaeta ${ }^{2}$ and Raúl Ulloa ${ }^{3}$
}

\begin{abstract}
${ }^{1}$ División de Investigación en Acuicultura, Instituto de Fomento Pesquero (IFOP), Balmaceda 252, Casilla 665, Puerto Montt, Chile.pablo.rojas@ifop.cl

${ }^{2}$ Laboratorio de Ictioplancton (LABITI), Facultad de Ciencias del Mar y de Recursos Naturales, Universidad de Valparaíso, Casilla 5080, Viña del Mar, Chile

${ }^{3}$ Universidad Autónoma de Nayarit, Postgrado Ciencias Biológicas Agropecuarias y Pesqueras, Ciudad de la Cultura Amado Nervo, CP 63000, Tepic, Nayarit, México
\end{abstract}

\begin{abstract}
Resumen.- Se analizó el impacto del fenómeno El Niño (1997-1998) sobre la dinámica espacial, así como sobre los cambios en los patrones de agregación de los huevos y larvas de anchoveta debido a la alteración de las anomalías térmicas. Se realizaron seis campañas bio-oceanográficas en el norte de Chile desde Arica (18 $\left.29^{\prime} \mathrm{S}, 70^{\circ} 19^{\prime} \mathrm{W}\right)$ a Antofagasta $\left(23^{\circ} 38^{\prime} \mathrm{S}, 70^{\circ} 24^{\prime} \mathrm{W}\right.$ ) durante diferentes períodos (antes y durante) del evento El Niño 1997-1998. Se registraron cambios en la distribución vertical y patrones de agregación de las larvas de anchoveta, así como un aumento de la biomasa de zooplancton con la llegada de El Niño; además, las preferencias ecológicas de la anchoveta fueron alteradas por el desplazamiento gradual hacia el sur de las zonas de desove como resultado de la llegada de aguas cálidas subtropicales. Un aumento en la biomasa del zooplancton vinculada a un cambio en la composición de especies sugiere un impacto negativo en la alimentación de las larvas de anchoveta. Los resultados obtenidos indicarían que cambios bruscos en el ambiente tendrían consecuencias inmediatas en la distribución de los estados tempranos de la anchoveta, causando un potencial impacto en el reclutamiento de esta especie pelágica en el Sistema de Corrientes de Humboldt frente al norte de Chile.
\end{abstract}

Palabras clave: Sistema de la Corriente de Humboldt-Chile, larvas de peces, anomalías térmicas, surgencia costera, zooplancton

\begin{abstract}
The impact of the El Niño event (1997-1998) on the spatial dynamics as well as on the changes in the aggregation patterns of anchoveta eggs and larvae due to the alteration in the thermal anomalies were analyzed. Six bio-oceanographic surveys were carried out in northern Chile from Arica (18 $\left.29^{\prime} \mathrm{S}, 7^{\circ} 19^{\prime} \mathrm{W}\right)$ to Antofagasta $\left(23^{\circ} 38^{\prime} \mathrm{S}, 70^{\circ} 24^{\prime} \mathrm{W}\right)$ over different periods (before and during) of the 1997-1998 El Niño event. Changes in the vertical distribution and aggregation patterns of anchoveta in early life stages were registered as well as an increase in zooplankton biomass with the arrival of El Niño; moreover, the spatial distribution of anchoveta was altered due to the gradually poleward displacement of spawning areas as a result of the arrival of subtropical warm waters from the north. The increase in zooplankton biomass linked to a change in the species composition suggests a negative impact on the anchoveta larval feeding. Our results suggest that abrupt changes in the environment would have immediate consequences on the spatial distribution of anchoveta in early life stages, causing a potential impact on the recruitment of this small pelagic fish in the Humboldt Current System off northern Chile.
\end{abstract}

Key words: Chile-Humboldt Current System, fish larvae, thermal anomaly, coastal upwelling, zooplankton

\section{INTRODUCTION}

The coastal upwelling zone of the Humboldt Current System (HCS) in the eastern South Pacific is well known for its high primary productivity (up to $20 \mathrm{~g} \mathrm{C} \mathrm{m}^{-2} \mathrm{~d}^{-1}$, Daneri et al. 2000, Montero et al. 2007), which sustains high zooplankton biomass and abundance of coastal and oceanic small pelagic fish such as anchoveta, sardine (Cushing 1990), horse mackerel (Alheit \& Bernal 1993, Cubillos et al. 2008) and sculpin (Landaeta et al. 2010). High coastal productivity is sustained mainly by the fertilizing effect of the coastal upwelling driven by 
equatorward alongshore wind stress, producing important nutrient supply to the euphotic zone above the continental shelf. Also, the offshore propagation of mesoscale eddies and meandering currents contributes significantly to expanding the area of high chlorophyll concentration beyond the coastal upwelling centre (Correa-Ramirez et al. 2007). The HCS is subject to strong inter-annual variability due to the effects of the El Niño Southern Oscillation events (ENSO). Probably due to the catastrophic collapse of the Peruvian fisheries after the 1972-1973 El Niño event, much of the actual knowledge about the effects of the ENSO over the HCS region comes from studies on Peruvian ecosystems. Numerous reports have approached both the physical variability (Fahrbach et al. 1991) and the biological consequences of the $\mathrm{El}$ Niño event on the pelagic ecosystems (Barber \& Chavez 1983, 1986, Thomas et al. 2001), benthic communities (Tarazona et al. 1988, Arntz \& Tarazona 1990), and fisheries (Alamo \& Bouchon 1987, Arntz \& Tarazona 1990). For Chilean waters, the warm phase of ENSO events negatively affects the settlement of gastropods (Moreno et al. 1998), cohort somatic growth and survival rates of coastal fishes (Hernández-Miranda \& Ojeda 2006), abundance and composition of pelagic copepods (Hidalgo \& Escribano 2001) and larval fishes (Rodriguez-Graña \& Castro 2003, Landaeta et al. 2009). However, during El Niño, the diversity of marine fishes increases (Kong et al. 1985) as well as the biomass of the calanoid copepod Calanus chilensis (Escribano \& Hidalgo 2000). Some reports on the upwelling systems off northern Chile $\left(18^{\circ}-30^{\circ} \mathrm{S}\right)$ have shown inter-annual fluctuation in the anchoveta catches (Blanco et al.2001) along with changes in the composition and abundance of plankton communities (Iriarte et al. 2000, González et al. 2002).

The effect of each of the El Niño events on the pelagic ecosystems of the southeastern Pacific ocean has differed over time, this difference being strongly related to the intensity and duration of each event, the period of maximum intensity, the season and especially in regards to the composition of the fauna present in the ecosystem at the time of its occurrence (Zebiak 1999). During the El Niño of 1997-1998 the phytoplankton community off Antofagasta $\left(23^{\circ} 38^{\prime} \mathrm{S}, 70^{\circ} 24^{\prime} \mathrm{W}\right)$ was mainly composed of small species, including diatoms and autotrophic flagellates. The zooplankton community off northern Chile during non-El Niño conditions was dominated mostly by large copepods and euphausiids endemic to the HCS (Hidalgo \& Escribano 2001, Fernández et al. 2002). However, time-series data of zooplankton from the
Antofagasta coast show a substitution toward small-sized species, although in general terms the total biomass close to the coast did not suffer a sudden collapse in comparison with previous years (Ulloa et al. 2001).

Regarding the commercially important pelagic species from northern Chile, the anchoveta Engraulis ringens is a fast growing species inhabiting coastal zones with high productivity rates (Bertrand et al. 2004a), whereas the sardine Sardinops sagax is associated to oceanic waters and frontal zones between these zones and the coastal waters (Castillo et al. 1996, Bertrand et al. 2004a). Anchoveta stocks in northern Chile are restricted to a temperature range fluctuating between $12^{\circ}-18^{\circ} \mathrm{C}$ during austral winter (unpublished data). Despite the importance of the information related to upwelling circulation in the Humboldt Current System (HCS) and its impact on the survival of eggs and fish larvae for the population dynamics of exploited fish, it is still insufficient and only limited to the anchoveta population (Engraulis ringens) from central-southern Chile (Castro et al. 2000, 2009, Hernández \& Castro 2000, Bustos et al. 2008).

Low oxygen concentrations in subsurface waters of coastal upwelling zones might also affect zoo- and ichthyoplankton vertical distribution (Pavez et al. 2010). In the Humboldt Current System the layer of low dissolved oxygen concentration is rather shallow (Minimum Oxygen Layer, <20 m) (Morales et al. 1996, Giesecke \& González 2004). The limits of temperature and oxygen tolerance for anchoveta and sardine in this region have been reported to fluctuate between $14^{\circ}-21^{\circ} \mathrm{C}$ and $16^{\circ}-23^{\circ} \mathrm{C}$, and between $1.8 \mathrm{ml} \mathrm{L}^{-1}$ and $2.0 \mathrm{ml} \mathrm{L}^{-1}$ respectively. These factors are often closely related (Morales et al. 1996). The above mentioned oxygen concentrations are found at $30 \mathrm{~m}$ depth and may be responsible for a restricted vertical distribution of the anchoveta.

Climatic changes at different time scales would be the responsible factors causing alterations to both the aggregation and spawning patterns of pelagic fish associated to coastal upwelling environments (Chavez et al. 2003, Bertrand et al. 2004a). In northern Chile, anchoveta showed similar responses to the effects of the El Niño event over the period 1957-2000, revealing a gradual decrease in abundance as the species approached the coast, with the sole exception of the 1992-1993 event where anchoveta abundance was not largely affected, despite the intensity of that event (Blanco et al. 2002).

Despite the confirmed ecological differences in the pelagic habitat between sardine and anchoveta 
associated with coastal upwelling zones off northern Chile, little is known about the effects on the distribution patterns of anchoveta eggs and larvae with the arrival of the El Niño 1997-1998 to the northern coast of Chile. The goal of this study is to analyze the consequences of the El Niño 1997-1998 on the Humboldt Current System off the northern coast of Chile at the epipelagic level, focusing mainly on the changes that occurred in the spatial distribution and aggregation patterns of the anchoveta eggs and larvae due to variations in thermal anomalies. Consequently we hypothesized that the spatial distribution of early life stages of anchoveta in coastal areas of northern Chile changed as El Niño 1997-98 event developed.

\section{Materials ANd Methods}

\section{OCEANOGRAPHIC SAMPLING}

During 1996, 1997 and 1998, the Instituto de Fomento Pesquero (IFOP) carried out six oceanographic cruises off northern Chile between Arica (18 $50^{\circ}$ 'S) and Antofagasta $\left(23^{\circ} 65^{\prime} \mathrm{S}\right)$. All surveys covered 34 stations along five transects, divided into offshore (beyond continental shelf, $>200 \mathrm{~m}$ depth) and nearshore (inside continental shelf with an extension of $\sim 15 \mathrm{~km}$ wide) stations: Cruise 1 (September 3-9, 1996); Cruise 2 (May 25-31, 1997), Cruise 3 (August 15-22, 1997); Cruise 4 (December 12-19, 1997); Cruise 5 (February 28-March 7, 1998) and Cruise 6 (May 25-June 3, 1998) (Fig.1). According to the recorded values of sea-surface temperature (SST) and thermal anomaly changes, the cruises were grouped into two categories: Before El Niño (Cruises 1-2-3) and During El Niño (Cruises 4-5-6). At each station, data on the temperature $\left({ }^{\circ} \mathrm{C}\right)$, salinity (PSU) and dissolved oxygen content $\left(\mathrm{ml} \mathrm{L}^{-1}\right)$, were obtained from the surface to $600 \mathrm{~m}$ by means of a SENSORIAL CTD OCEAN model OS 200. Inter-annual variability in the monthly anomalies of SST was estimated by subtracting the average annual cycle in the period 19661999. Satellite NOAA images of SST were used in the analysis of the evolution of the El Niño event for the period 1995-1999. Off the northern Chilean coast (1850'$\left.23^{\circ} 65^{\prime} \mathrm{S}\right)$ monthly averages of SST were obtained and subsequently monthly anomalies were calculated using the climatologically distribution average of SST in the study area.
Figure 1. Geographic location of stations and transect off the northern coast of Chile. The continuous and discontinuous line shows the location of coastal and oceanic stations, respectively / Localización geográfica de las estaciones y transectos frente a las costas del norte de Chile. Las líneas continua y discontinua muestran la ubicación de las estaciones costeras y oceánicas, respectivamente

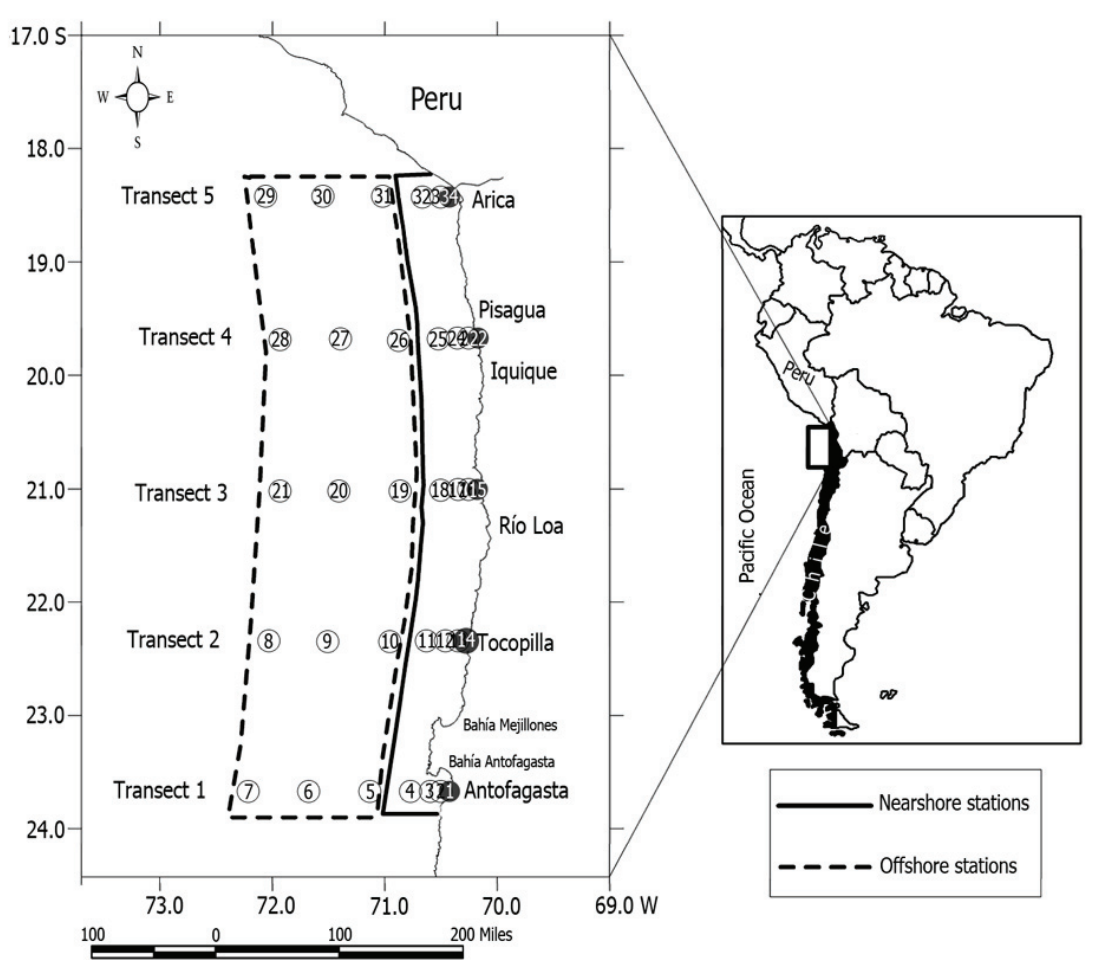

Vol. 46, N³, 2011407 


\section{SAMPLING AND ANALYSIS OF ICHTHYOPLANKTON}

Zooplankton was collected through stratified vertical samplings (0-20; 20-60 and 60-100 $\mathrm{m}$ depth). A WP-2 net was utilized, with an opening mouth of $57 \mathrm{~cm}$ diameter $\left(0.25 \mathrm{~m}^{2}\right.$ mouth area), total length of $261 \mathrm{~cm}$ and $297 \mu \mathrm{m}$ mesh size, equipped with a double opening-closing system, and a calibrated TSK flowmeter. A total of 204 samples were collected throughout the surveys, and preserved in $4 \%$ buffered formalin. In the laboratory, anchoveta eggs and larvae were removed for counting and identification, following Orellana \& Balbontín (1983). Zooplankton biomass was measured through displaced volume of wet weight. The number of individuals collected in the different sampling strata was standardized to a number per unit of volume of filtered water (densities): $1,000 \mathrm{~m}^{3}$ for fish larvae (densities) for comparisons in the vertical axis (mean depth). The integrated abundance of eggs and larvae in the water column (larvae $10 \mathrm{~m}^{-2}$ ) was also estimated for each sampling station.

For the analysis and display of spatial information GIS, ArcView version 3.3 (ESRI 1996) was utilized. Data were analyzed using raster or grid models (Bosque-Sendra 1992). Files that contained the physical and biological attributes collected at each station were converted into SHAPE files. Coverage of points for each cruise was generated from these files. Furthermore, continuous surface grids were generated through the interpolation method, which were subsequently analyzed using the SURFACE module from ArcView. The grids were conducted at a distance of $10 \mathrm{~km}$ between points using a surface interpolation technique: IDW (Jongman et al. 1995), this method assumes that each point has a local influence that decreases with distance and does not require a semi-variogram. The IDW interpolation was used to generate grids of thermal anomaly, calculated on the basis of average monthly sea-surface temperature for the different cruises.

\section{DATA PROCESSING}

Kruskal-Wallis test (1952) was applied to determine differences within eggs and larvae abundance and zooplankton biomass, using the location of the stations (coastal/oceanic) and periods (Before El Niño/During El Niño) as factors. To investigate the relationship between oceanographic variables and the anchoveta larvae and egg abundance as well as zooplankton biomass, Principal Component Analysis (PCA) was utilized (Jongmann et al. 1995), over $\log (\mathrm{x}+1)$ transformed data to homogenize variances. This technique consists of identifying 'a minimum set of functional components' (oceanographic variables) to explain the distribution of dependent variables (larvae and eggs distribution). The Spearman correlation analysis (Hays 1981) was utilized to investigate changes in the relationships between biological (i.e., anchoveta eggs-larvae and zooplankton abundance) and physical variables (i.e., SST, thermal anomalies, salinity and oxygen) during different El Niño conditions. All statistical analyses were conducted using STATISTICA 7.0 software package.

\section{Results}

Physical environmental anomalies before El Niño The spatial distribution of sea-surface temperature (SST; Fig.2) registered during September 1996 (austral spring) showed values fluctuating between $14.0-16.7^{\circ} \mathrm{C}$, with cold zones corresponding to recently upwelled waters (Fig. 2a). For May 1997 (autumn), an increase in the surface temperature was observed with values from 18.0 to $22.4^{\circ} \mathrm{C}$, although some isolated centres of cold water remained nearshore (Fig. 2b). In August 1997 (winter) the SST oscillated between $17.5-20.6^{\circ} \mathrm{C}$, with a strong presence of warm waters covering an area that includes Bahía Mejillones (Fig. 2c). The salinity registered in September 1996 showed values ranging between 34.4-34.9 psu, typical for Equatorial Subsurface Waters (ESSW). A small increase in salinity 34.7-35.3 psu was observed in May 1997 associated with revenue warm water from a subtropical origin (Fig. 3). The concentration of dissolved oxygen found during September 1996, May 1997 and August 1997 showed relatively stable levels ranging between 4.0-6.9 $\mathrm{ml} \mathrm{L}^{-1}$ (Table 1).

\section{Thermal ANOMALIES}

The warm SST anomalies reported in the Equatorial Pacific $^{1}$ clearly showed the El Niño events of 1982-83, 1987, 1991-1992 and 1997-98. While these events have been of different intensities, the local SST data shows an increase in anomaly values for coastal areas, mainly associated with upwelling zones (Fig. 4). According to information, the manifestation of the 1997-1998 El Niño event showed warm water anomalies in May 1997, reaching values of $+1^{\circ} \mathrm{C}$ between August and December.

${ }^{1}<$ http: //www.cpc.ncep.noaa.gov> 


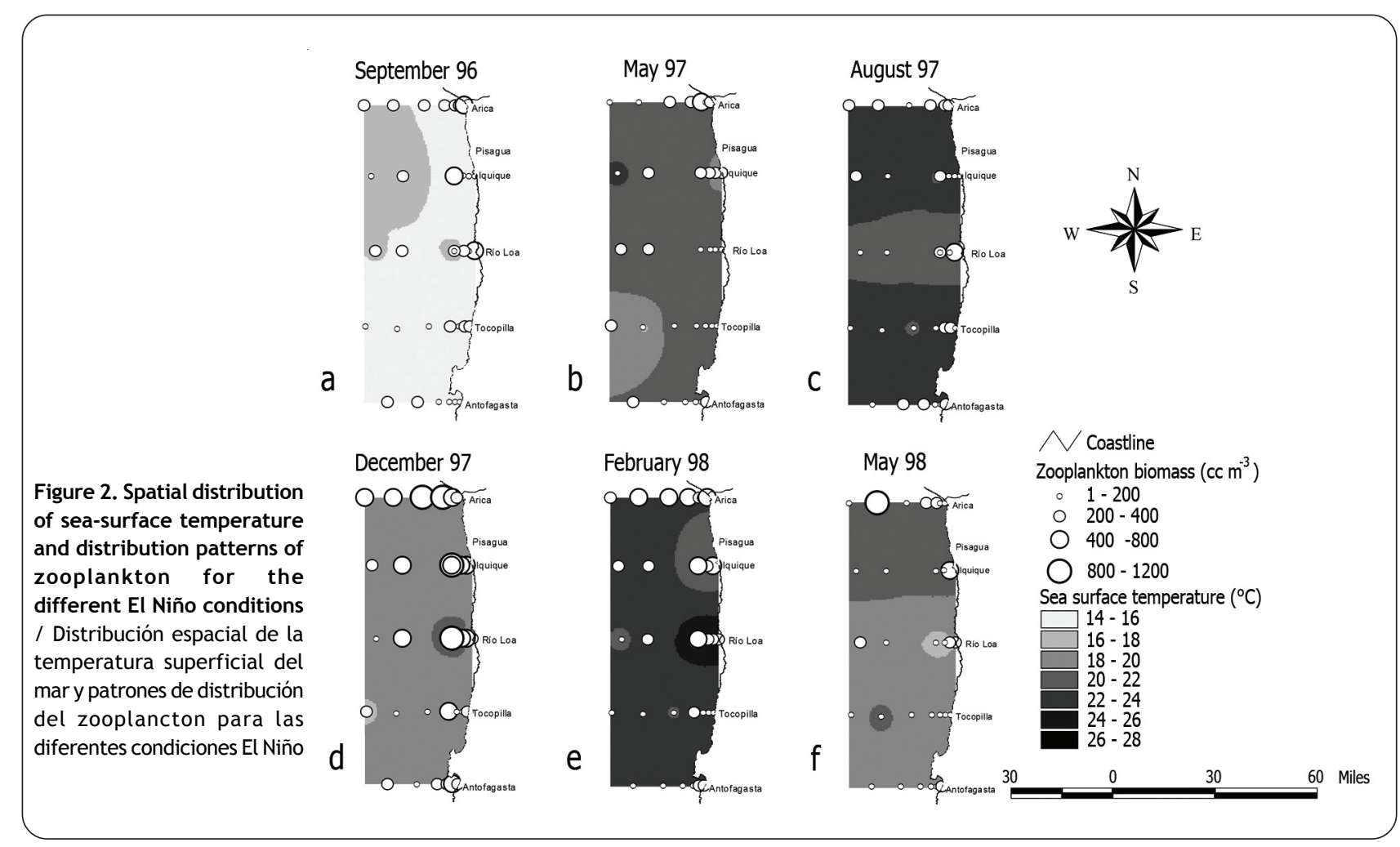

Figure 3. Relation between salinity and sea temperature for the different cruises, indicating the period where the study area is affected by Subtropical Surface Waters. Bars indicate values of standard deviation / Relación entre la salinidad y la temperatura del mar para las diferentes campañas, indicando los períodos donde el área de estudio es afectada por Aguas Superficiales Subtropical. Las barras indican los valores de desviación estándar

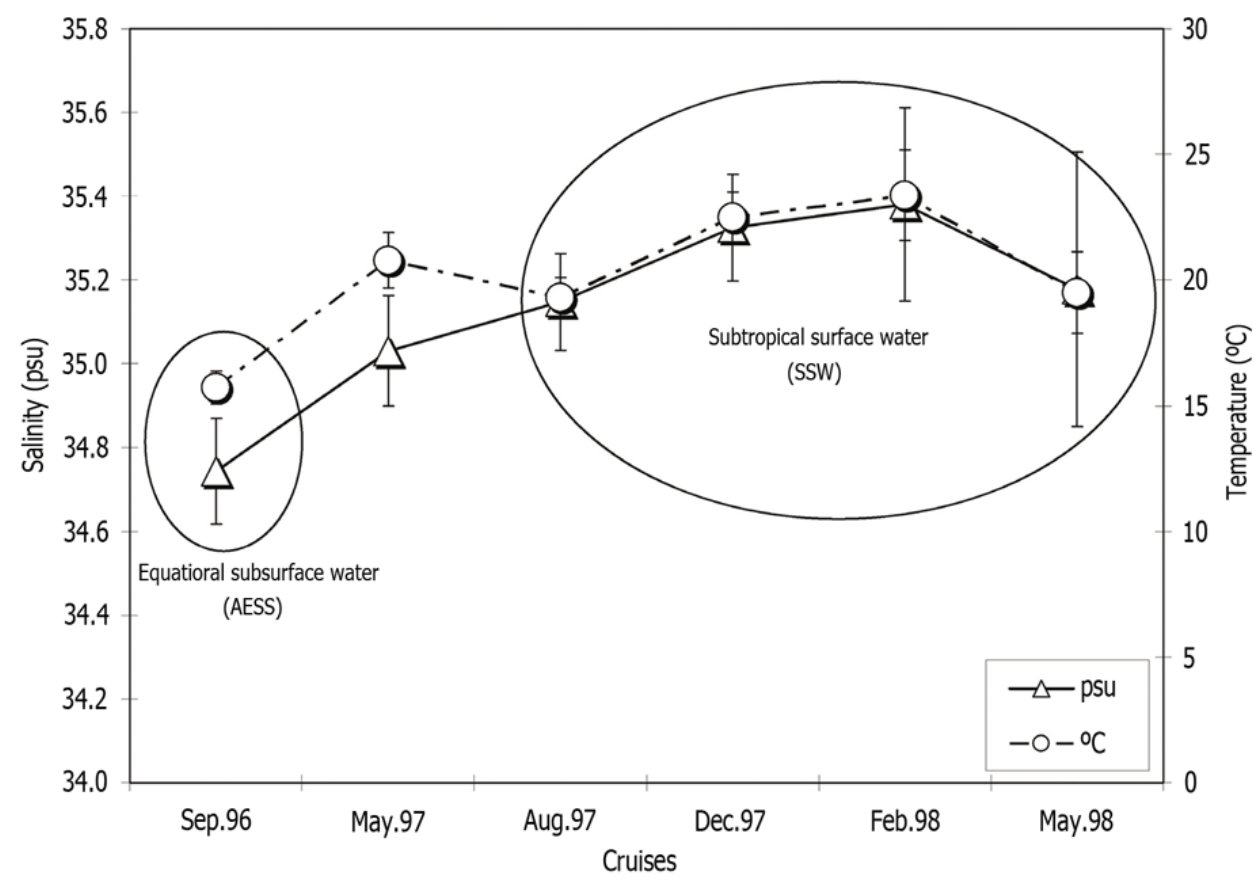


Table 1. Summary of the oceanographic conditions for the different cruises $(n=34)$. SD = standard deviation / Resumen de las condiciones oceanográficas en los diferentes cruceros ( $n=34)$. SD = desviación estándar

\begin{tabular}{lcccccc}
\hline & \multicolumn{3}{c}{ Before El Niño } & \multicolumn{3}{c}{ During El Niño } \\
\cline { 2 - 7 } Hydrographic condition & Sep.96 & May.97 & Aug.97 & Dec.97 & Feb.98 & May.98 \\
\hline Temperature $\left({ }^{\circ} \mathrm{C}\right.$ ) & & & & & & \\
Range (min-max) & $14.0-16.7$ & $18.0-22.4$ & $17.5-20.6$ & $20.2-24.1$ & $20.6-26.2$ & $16.5-21.9$ \\
Mean & 15.7 & 20.8 & 19.3 & 22.5 & 23.4 & 19.5 \\
SD & 0.6 & 1.1 & 0.8 & 1.0 & 1.8 & 1.6 \\
Thermal anomalies $\left({ }^{\circ} \mathrm{C}\right)$ & & & & & & \\
Range (min-max) & $-1.7-0.5$ & $0.03-5.0$ & $1.5-4.5$ & $0.05-4.9$ & $0.3-4.7$ & $-1.3-3.2$ \\
Mean & -0.8 & 2.1 & 3.1 & 2.9 & 2.4 & 0.8 \\
SD & 0.5 & 1.1 & 0.6 & 1.3 & 1.1 & 0.8 \\
Salinity (PSU) & & & & & & \\
Range (min-max) & $34.4-34.9$ & $34.7-35.3$ & $34.8-35.3$ & $35.1-35.5$ & $35.0-35.8$ & $34.7-35.7$ \\
Mean & 34.7 & 35.0 & 35.1 & 35.3 & 35.4 & 35.2 \\
SD & 0.1 & 0.1 & 0.1 & 0.1 & 0.2 & 0.3 \\
Oxygen (ml L-1) & & & & & & \\
Range (min-max) & $4.0-6.9$ & $4.2-6.4$ & $4.5-6.7$ & $4.2-6.8$ & $4.3-5.8$ & $4.4-5.8$ \\
Mean & 5.8 & 5.3 & 5.6 & 5.5 & 5.0 & 5.2 \\
SD & 0.6 & 0.4 & 0.5 & 0.4 & 0.3 & 0.2 \\
\hline
\end{tabular}

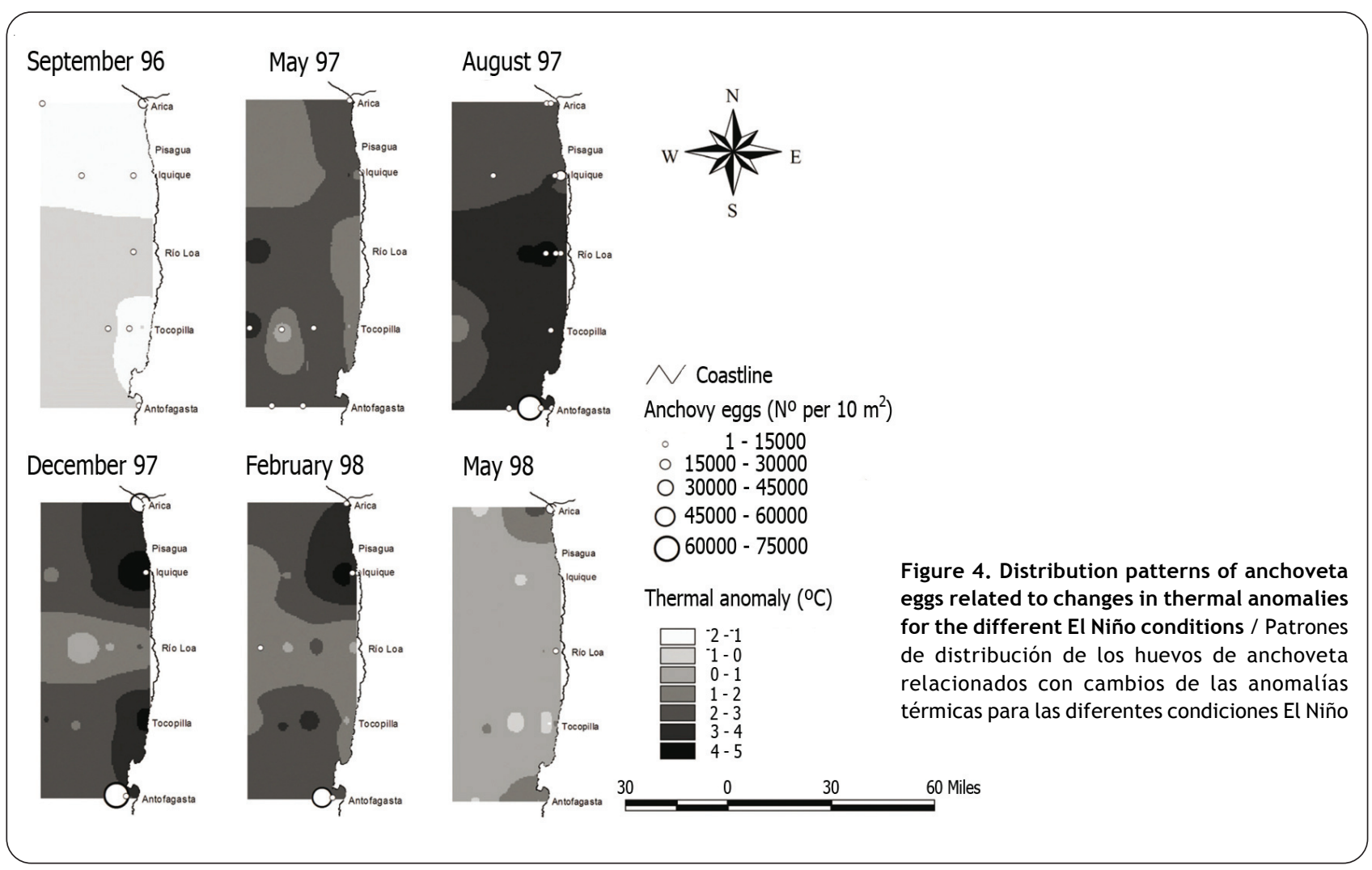




\section{Distribution AND ABUndance OF ZOOPLANKTON BIOMASS}

Periods were characterized by differences in the distribution and abundance of zooplankton. In September 1996 the highest biomass concentrations were located at nearshore stations associated with cold waters. In May 1997 - August 1997, a clear decrease in zooplankton values associated with the presence of warm waters of subtropical origin were observed (Fig. 2).

An important signal regarding anchoveta egg abundance $\left(29,539\right.$ eggs per $\left.10 \mathrm{~m}^{2}\right)$ for the nearshore stations off Arica was detected in September 1996 (Fig. 4). The distribution and abundance of anchoveta larvae in September 1996 was relatively homogenous in most stations. However, two centres of higher larval abundance were found in the stations nearshore to Arica and Rio Loa (19,916 and 14,958 ind. per $10 \mathrm{~m}^{2}$, respectively). In May 1997, all the stations registered a low abundance of anchoveta eggs and larvae, particularly for nearshore areas (Figs. 4 and 5). The August 1997 cruise showed a general low abundance of anchoveta eggs and larvae. However, two zones which showed a large abundance of anchoveta eggs (71,908 eggs per $\left.10 \mathrm{~m}^{2}\right)$ and larvae $(17,614$ ind. per $10 \mathrm{~m}^{2}$ ) were found in the nearshore stations of
Antofagasta (Fig. 6). In general, the larvae show a lowabundance $\left(>250\right.$ per $\left.1,000 \mathrm{~m}^{3}\right)$ in most stations. An increase in fish larvae abundance from South to North was found in the study area, mainly associated with surface layers in those nearshore stations.

\section{Physical environmental anomalies during El Niño}

The SST in December 1997 (austral summer) demonstrated the arrival of El Niño to the northern coast of Chile with values of $20.2-24.1^{\circ} \mathrm{C}$, with the intrusion of warm waters extending to Antofagasta (Fig. 2d). During February 1998 (summer) SST oscillated between $20.6-26.2^{\circ} \mathrm{C}$, indicating that the El Niño condition was maintained in the area (Fig. 2e). The SST values for May 1998 (autumn) fluctuated between $16.5-21.9^{\circ} \mathrm{C}$. Figure $2 \mathrm{f}$ shows the presence of sea water $<22^{\circ} \mathrm{C}$ in the studied area, and a near area with cold $\left(16-18^{\circ} \mathrm{C}\right)$ waters. In December 1997 the salinity showed values that fluctuated between 34.8-35.8 psu typical for Subtropical Surface Waters (SSW). No significant differences were detected in the salinity values before and during El Niño (Fig. 3). During December 1997, February 1998 and May 1998, a decrease in the maximum oxygen values was also observed (Table 1).
Figure 5. Distribution patterns of anchoveta larvae related to changes in thermal anomalies for the different El Niño conditions / Patrones de distribución de larvas de anchoveta relacionados con cambios de las anomalías térmicas para las diferentes condiciones El Niño

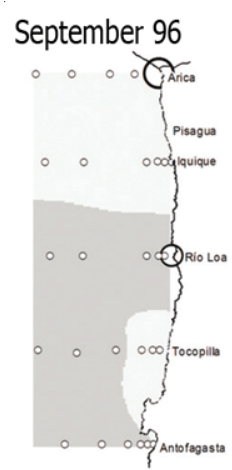

\section{December 97}

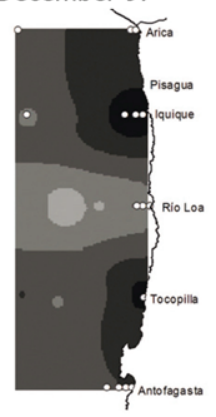

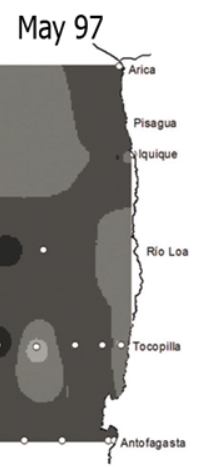

February 98

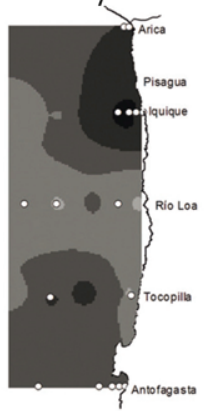

August 97
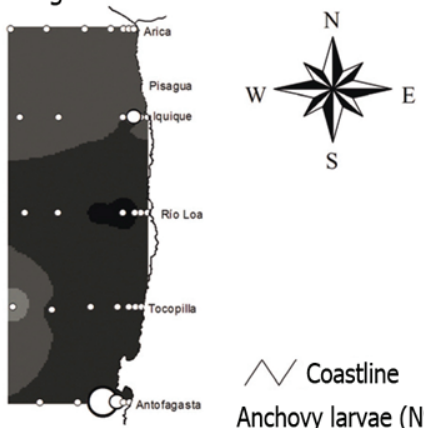

$\wedge$ Coastline

Anchovy larvae ( $\mathrm{N}^{0}$ per $10 \mathrm{~m}^{2}$ )

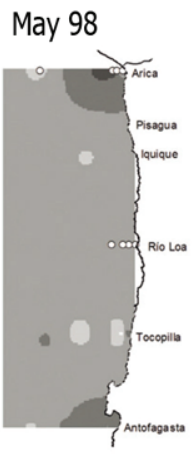

$1-5000$

○ $5000-10000$

○ $10000-15000$

○15000- 20000

Thermal anomaly $\left({ }^{\circ} \mathrm{C}\right)$

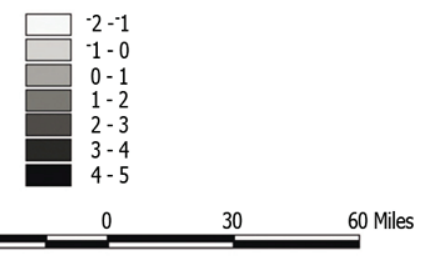




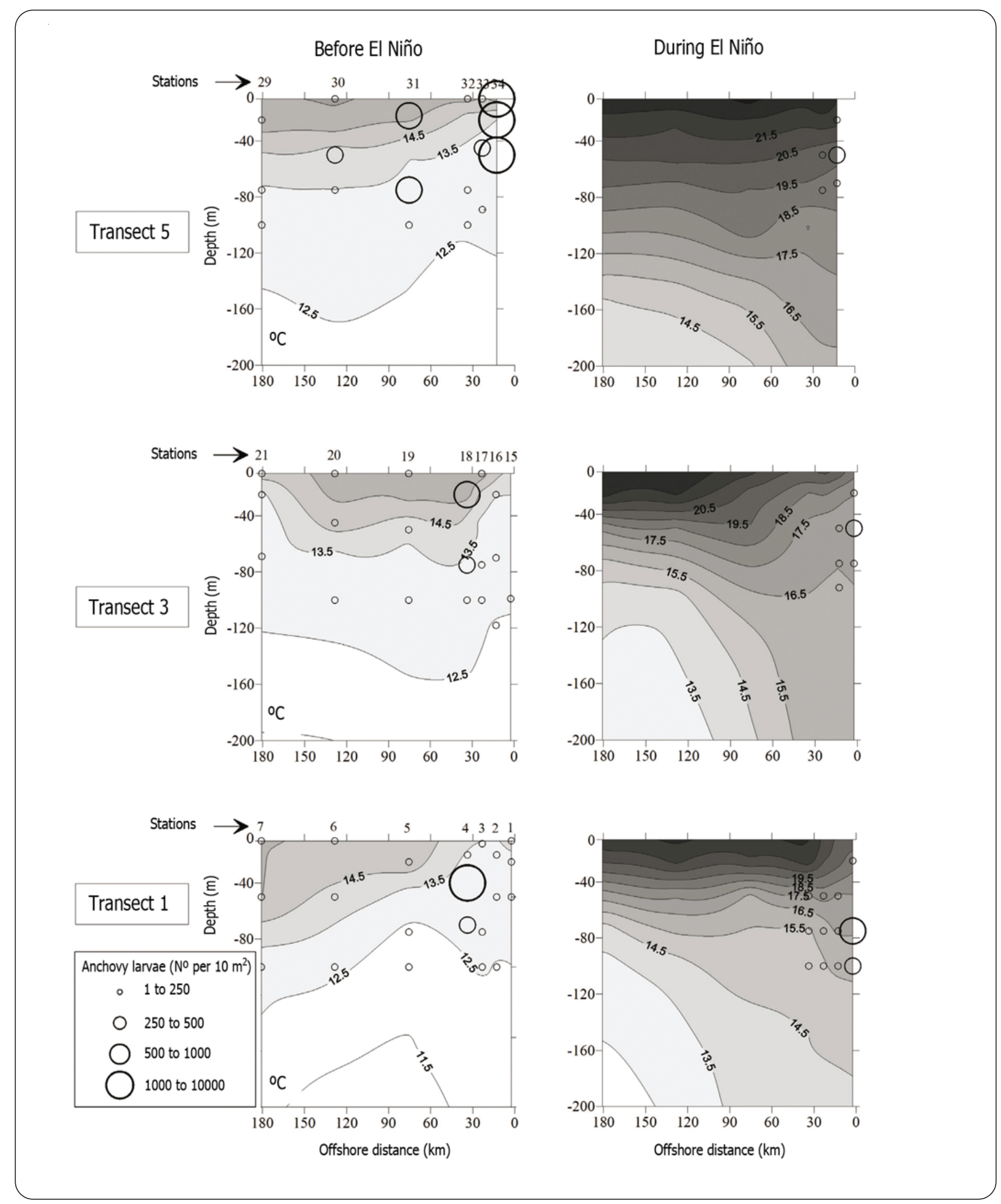

Figure 6. Vertical distribution of anchoveta larvae at three transects for different El Niño conditions / Distribución vertical de larvas de anchoveta en tres transectas para las diferentes condiciones El Niño 


\section{Thermal ANOMALIES}

In December 1997 and February 1998 the study area showed high thermal anomaly values mainly in coastal stations associated with cold upwelling waters, whereas during the May 1998 cruise a decrease in the thermal anomaly values was registered, which indicates that the phenomenon began to move away (Fig. 4).

\section{Distribution AND abundance of zoOplankton BIOMASS}

The zooplankton biomass showed high spatial variability during each cruise, being highly abundant $\left(>800 \mathrm{cc} \mathrm{m}^{-3}\right)$ in the coastal stations off Arica, Iquique and Río Loa during December 1997 (Fig. 2d). A similar spatial trend was observed during February and May 1998. However, zooplankton biomass did not differ among cruises nor between El Niño conditions (Table 3).

\section{SPATIAL DISTRIBUTION OF ANCHOVETA EGGS AND LARVAE}

Except for December 1997, abundance of anchoveta eggs was low $\left(<15,000\right.$ eggs $\left.10 \mathrm{~m}^{-2}\right)$ throughout the sampled study area (Fig. 4). Two isolated clusters of anchoveta eggs were registered in nearshore zones off Arica and Antofagasta in December 1997 (Figs. 4). The abundance of anchoveta larvae was low during the December 1997 cruise. In February 1998 the highest egg density $(58,937$ eggs $10 \mathrm{~m}^{-2}$ ) was collected at the nearshore stations off Antofagasta, where low larval abundance was found. During May 1998, results showing a low abundance of anchoveta larvae was obtained (mean $\pm \mathrm{SD}, 94 \pm 340$ ind. $10 \mathrm{~m}^{-2}$, Table 2), however restricted only to some nearshore stations off Arica, Rio Loa and Tocopilla. During this period the vertical distribution of anchoveta larvae was influenced by the increase of surface temperature, limiting aggregations near the coast above the $15^{\circ} \mathrm{C}$ isotherm and at mid-depths (20-100 m depth) (Fig. 6).

\section{RELATIONSHIP OF BIOLOGICAL VARIABLES WITH THE DIFFERENT EL Niño CONDITIONS}

There were significant differences in the abundance of larval anchoveta among cruises (K-W test, $F_{(1,201)}=26.32$; $P<0.001)$, as well as among stations $\left(F_{(1,201)}=9.36 ; P<\right.$ $0.05)$. The egg abundance showed important seasonal differences $\left(F_{(1,201)}=5.40 ; P<0.05\right)$ and significant differences $\left(F_{(1,201)}=5.79 ; P<0.05\right)$ in egg abundance were observed between inshore and offshore stations (Table 3).

Table 2. Average values of zooplankton biomass and anchoveta eggs-larvae registered for the different time periods / Valores promedio para la biomasa de zooplancton, huevos y larvas de anchoveta en los diferentes periodos

\begin{tabular}{|c|c|c|c|c|c|c|}
\hline \multirow[b]{2}{*}{ Biomass } & \multicolumn{3}{|c|}{ Before El Niño } & \multicolumn{3}{|c|}{ During El Niño } \\
\hline & Sep.96 & May.97 & Aug.97 & Dec.97 & Feb.98 & May.98 \\
\hline \multicolumn{7}{|l|}{ Zooplankton ( $\left.\mathrm{cc} \mathrm{m}^{-3}\right)$} \\
\hline Range (min-max) & $79-484$ & $33-416$ & $61-534$ & $63-1331$ & $54-758$ & $35-888$ \\
\hline Median & 218 & 176 & 192 & 399 & 252 & 109 \\
\hline Mean & 240 & 192 & 197 & 450 & 307 & 164 \\
\hline SD & 103 & 107 & 95 & 284 & 190 & 177 \\
\hline \multicolumn{7}{|l|}{$\operatorname{Eggs}\left(\mathrm{N}^{\circ} 10 \mathrm{~m}^{-2}\right)$} \\
\hline Range (min-max) & $0-29,539$ & $0-6,751$ & $0-71,908$ & $0-66,293$ & $0-58,937$ & $0-16,871$ \\
\hline Median & 1,265 & 621 & 829 & 1,726 & 4,038 & 8795 \\
\hline Mean & 1,356 & 269 & 3,239 & 3,730 & 2,233 & 517 \\
\hline SD & 5,198 & 1,167 & 12,529 & 14,779 & 10,180 & 2,892 \\
\hline \multicolumn{7}{|l|}{ Larvae $\left(\mathrm{N}^{\circ} 10 \mathrm{~m}^{-2}\right)$} \\
\hline Range (min-max) & $0-19,916$ & $0-1,510$ & $55-17,614$ & $0-3,933$ & $0-2,243$ & $0-1,937$ \\
\hline Median & 371 & 93 & 550 & 256 & 113 & 169 \\
\hline Mean & 1,526 & 109 & 1,780 & 315 & 134 & 94 \\
\hline SD & 4,126 & 305 & 3,369 & 784 & 396 & 340 \\
\hline
\end{tabular}


Table 3. Results of Kruskal-Wallis test for anchoveta eggs-larvae abundance and zooplankton biomass with EI Niño conditions (before El Niño/during El Niño) and station locations (nearshore/ offshore) / Resultados del test Kruskal-Wallis para la abundancia de huevos y larvas de anchoveta, biomasa de zooplancton con las distintas condiciones El Niño (antes El Niño/durante El Niño) y con la ubicación de las estaciones (cerca de la costa/mar adentro)

\begin{tabular}{lrrrrl}
\hline Source & \multicolumn{1}{l}{ SS } & df & \multicolumn{1}{c}{ MS } & $F$-ratio & $P$-level \\
\hline Eggs & & & & & \\
$\quad$ El Niño & 11.17 & 1 & 11.17 & 5.40 & $0.021^{*}$ \\
Stations & 11.98 & 1 & 11.98 & 5.79 & $0.017^{*}$ \\
Interaction & 0.71 & 1 & 0.71 & 0.34 & 0.560 \\
Error & 416.09 & 201 & 2.07 & & \\
Larvae & & & & & \\
El Niño & 83.66 & 1 & 83.66 & 26.32 & $0.000^{* *}$ \\
Stations & 29.74 & 1 & 29.74 & 9.36 & $0.003^{*}$ \\
Interaction & 9.32 & 1 & 9.32 & 2.93 & 0.088 \\
Error & 638.84 & 201 & 3.18 & & \\
Zooplankton & & & & & \\
El Niño & 0.16 & 1 & 0.16 & 0.03 & 0.862 \\
Stations & 17.76 & 1 & 17.76 & 3.32 & 0.070 \\
Interaction & 0.09 & 1 & 0.09 & 0.02 & 0.894 \\
Error & 1076.02 & 201 & 5.35 & & \\
\hline
\end{tabular}

$* P<0.05 ; * * P<0.001$

The Principal Component Analysis (PCA) between biological variables (e.g., anchoveta eggs-larvae and zooplankton biomass) and oceanographic variables before El Niño showed that the two first components explained $70.19 \%$ of the variance. In this period two types of associations were observed: the first group was composed of biological variables associated with high levels of dissolved oxygen (4.5-6.7 $\left.\mathrm{ml} \mathrm{L}^{-1}\right)$, and the second group was composed only of oceanographic variables (e.g., SST; Salinity) (Fig. 7a). During the El Niño, the two first components explained $63.91 \%$ of the variance. Moreover, similarly to the previous period, two other associations were detected: the first group the zooplankton to high values of sea-surface temperature and salinity. The second group was composed of anchoveta eggs and larvae associated with dissolved oxygen (Fig. 7b).

\section{RELATIONSHIP BETWEEN PHYSICAL AND BIOLOGICAL VARIABLES}

Before El Niño conditions, anchoveta larvae showed a significant positive relationship with thermal anomalies, and a negative relationship with salinity (Table 4). Anchoveta eggs showed significant negative relationships with SST and salinity. Zooplankton showed
Table 4. Spearman correlation coefficient between different biological variables during the EI Niño conditions and sea-surface temperature (SST), thermal anomaly, salinity and dissolved oxygen. Zoo = zooplankton biomass / Coeficientes de correlación $\mathrm{R}$ Spearman entre las diferentes variables biológicas durante las diferentes condiciones El Niño con la temperatura superficial del mar (SST), anomalías térmicas, salinidad y oxigeno disuelto. Zoo= biomasa de zooplancton

\begin{tabular}{llllll}
\hline Condition & Variables & SST & Anomaly & Salinity & Oxygen \\
\hline \multirow{2}{*}{ Before El Niño } & Larvae & -0.15 & $0.43^{*}$ & $-0.48^{*}$ & -0.29 \\
& Eggs & $-0.57^{*}$ & 0.26 & $-0.53^{*}$ & $-0.53^{*}$ \\
& Zoo & -0.09 & $0.36^{*}$ & -0.15 & $0.55^{*}$ \\
\multirow{2}{*}{ During El Niño } & Larvae & $-0.52^{*}$ & $0.45^{*}$ & -0.30 & 0.12 \\
& Eggs & $-0.36^{*}$ & $0.64^{*}$ & -0.17 & 0.20 \\
& Zoo & $0.64^{*}$ & -0.07 & $0.69^{*}$ & 0.14 \\
\hline
\end{tabular}

$* P<0.05$

positive and significant changes with thermal anomalies and dissolved oxygen concentrations. In general, during this period low correlation coefficients $(\mathrm{r} \sim 0.4-0.5)$ were estimated between biological and physical variables (Table 4).

During El Niño conditions, anchoveta eggs and larvae showed significant relationships with changes in thermal anomalies and SST, with low correlation coefficients $(\mathrm{r}$ $\sim 0.5$; Table 4). Anchoveta larvae showed a negative and significant relationship with salinity values. It is remarkable the strong positive relationship detected between zooplankton biomass and SST and salinity; however, only with salinity did the zooplankton biomass show a high correlation coefficient $(r \sim 0.7)$.

\section{Discussion}

In this study, the abundance of anchoveta eggs and larvae showed variations in their distribution patterns during El Niño 1997-98 conditions, while the traditional spawning sites for anchoveta (Loeb \& Rojas 1988) were gradually moved southward as the El Niño intensified. This disturbance is explained both by changes in the positive thermal anomalies that increased gradually $\left(\sim 3.5-4^{\circ} \mathrm{C}\right)$ with the arrival of El Niño conditions, as well as by high salinity, which is a typical feature of surface water bodies of subtropical origin. With the onset of the El Niño event, warm water $\left(>15^{\circ} \mathrm{C}\right)$ was moved southward due to a weakening of the upwelling. In the 1997-1998 period, the $15^{\circ} \mathrm{C}$ isotherm remained at $70 \mathrm{~m}$ depth and was located 50 nautical miles offshore while on the surface the physical effects to El Niño reached central-southern Chile (Arcos et al. 2001). 

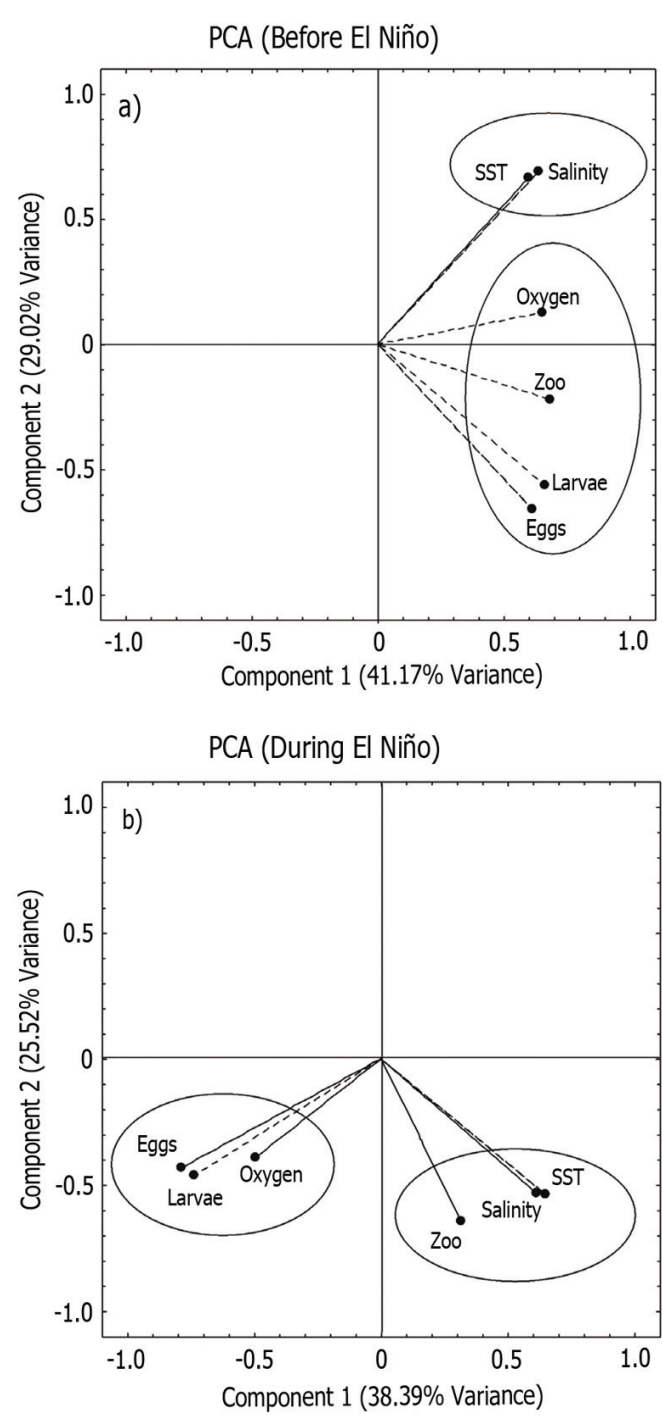

Figure 7. Projection of components 1 and 2 of the Principal Component Analysis (PCA), for the physical and biological variables in different EI Niño conditions. SST= sea-surface temperature; Zoo= zooplankton biomass / Proyección de los componentes 1 y 2 del Análisis de Componentes Principales (ACP), para las variables físicas y biológicas, en diferentes condiciones $\mathrm{El}$ Niño. SST $=$ temperatura superficial del mar; $Z 0 o=$ biomasa del zooplancton

During the warm phase of El Niño 1997-1998, surface waters were warmer $\left(>20^{\circ} \mathrm{C}\right)$, the fronts weakened or disappeared (Blanco et al. 2002), and the photic layer deepened below $100 \mathrm{~m}$ (Gonzalez et al. 1998). Along with the changes in the water bodies associated with the coastal zone, the thermocline, oxycline and minimum oxygen layer (MOL) also deepened, causing oxygenation of the subsurface waters near the shelf and shelf break (Blanco et al. 2002). The coastal upwelling persisted during the warm phase (Carr et al. 2002) but the nutricline deepened, thus limiting the input of new nutrients to the photic area and favouring regenerated production (Carr 2003).

The measurements made during these cruises correspond to a transition summer of an El Niño event (or Pre-El Niño, January 1997) and an El Niño Winter (July 1997). The effects of El Niño 1997-1998 began to register as a positive thermal anomaly since March 1997, however, January 1997 can be considered as a transition between La Niña and El Niño conditions, which was marked by very clear days and a relaxation of the upwelling favourable winds (Rutllant 1993²). As a result, an anomalous decrease in the frequency and magnitude of upwelling events at the study area also occurred. Based on satellite images of sea surface temperature (IGOSS, NOAA image), it was found that during December 1997 the positive thermal anomaly was approximately $3-4^{\circ} \mathrm{C}$ (González et al. 1998).

An immediate consequence to the organisms that face a physical environment with the oceanographic features mentioned above, involves acquiring the ability to continually adjust to the components of low-frequency variation, or to face the risk of being unable to adapt to local conditions (Bakun 2001). We have observed that in response to the arrival of warm waters during the active phase of the El Niño event, anchoveta larvae gradually deepen its vertical distribution at the same time that the thermocline was deepened below $50 \mathrm{~m}$, in response to the entrance of Kelvin waves in nearshore areas (Escribano et al. 2004). However, it is known that the Humboldt Current System presents an extensive minimum oxygen layer near the surface (<100 m depth; Morales et al. 1996) with low concentration values (approx. $1.0 \mathrm{ml} \mathrm{O}_{2} \mathrm{~L}^{-1}$ ) in its higher limit, associated to the intrusion of water masses of equatorial subsurface origin, as well as to cold waters from coastal upwelling. Thus, the depth attained by the anchoveta larvae through vertical migration could not exceed the upper limit of the minimum oxygen layer.

From an evolutionary perspective, the anchoveta has adapted to the coastal upwelling ecosystems of northern

${ }^{2}$ Rutllant J. 1993. Coastal lows and associated southerly winds events in north-central Chile. Preprints of the IV International Conference on Southern Hemisphere Meteorology and Oceanography, pp. 268-269. American Meteorological Society, Hobart, Australia, 29 March - 2 April 1993. 
Chile, taking advantage of high levels of chlorophyll as well as favourable oceanographic and topographic characteristics present at some sites during the active upwelling phase to spawn in a highly favourable habitat providing food, protection and growth for the larvae and post-larvae of pelagic species (Rojas 2003). However, a period of environmental stress caused by the El Niño event has an immediate effect on the anchoveta population which are moving their usual spawning sites southwardly (Espino 1999). The immediate impact on the anchoveta populations is highlighted through the differences in the distribution patterns observed for its early life stages over the different campaigns. Alterations in the aggregation patterns caused by strong environmental changes adversely affect the ecological relationships, among others: the feeding behaviour, the susceptibility of the species to natural predation (e.g., predator-prey relationships), distribution of spawning areas and therefore, the future abundance of the population (Perry et al. 2002). For example, in regards to the cod from the northwest Atlantic, the changes in the aggregation patterns of its larvae had a strong impact on the population dynamics, altering the susceptibility of this species to fishing pressures (Rose \& Kulka 1999).

With the arrival of warm surface water during El Niño conditions, high levels of zooplankton biomass on the northern coast of Chile have been recorded. The presence of warm water masses would produce an ecological replacement of plankton (Lluch-Belda et al. 2005) and a change in the size structure of the zooplankton, from large to a smaller size (Ulloa et al. 2001). This replacement in the phyto- and zooplankton composition could be due mostly to exotic species that differ in shape and size to the actual ones found during cold non-El Niño conditions (González et al. 2000, Hidalgo \& Escribano 2001). Anchoveta larvae are able to directly feed on phytoplankton; however, this small pelagic fish might not have a diet mainly based on filtering phytoplankton, due to its ability for capturing prey (Konchina 1991, Van der Lingen 2002) which is composed mainly of dinoflagellates, microzooplankton, small copepods and crustacean larvae (Llanos et al. 1996, Llanos-Rivera et al. 2004). Thus, anchoveta are incapable of sustaining growth based exclusively on a diet composed of phytoplankton (Espinoza et al. 2000). Consequently, high mortality rates may result because of a low availability of trophic resources in some coastal areas of northern Chile, forcing the species to use energy storage (Cubillos et al. 2001) that involves changing its reproductive tactics while waiting for favourable environmental conditions (i.e., skipping spawning).
The multivariate analysis showed changes in the relationships between the physical and biological variables during different El Niño conditions. Before the E1 Niño event, anchoveta larvae and eggs were concentrated mainly in coastal stations with intermediate values of dissolved oxygen $\left(\sim 5.5 \mathrm{mg} \mathrm{L}^{-1}\right)$ and a low abundance $\left(\sim 300 \mathrm{cc} \mathrm{m}^{-3}\right)$ of zooplankton biomass. This suggests that during this period the associations among different variables would not be so strong. During the El Niño event both anchoveta larvae and eggs show a marked segregation only with oxygen values close to 5 $\mathrm{mg} \mathrm{L}^{-1}$, not so with other hydrographic variables. Thus, it is reasonable to assume that the different distribution patterns of anchoveta eggs and larvae found off the northern Chilean coast would be the result of an ongoing search of favorable environmental conditions that apparently are influenced by oxygen.

Changes in the typical reproductive seasonality (Cubillos et al. 2001) of the anchoveta probably represent variability in the distribution of eggs and larvae in relation to environmental alterations in the short, medium and long term. The thermal conditions in northern Chile during periods before and after El Niño and its relation to the anchoveta distribution patterns partially explain the displacement of anchoveta spawning areas. The effect of the progressive increase in temperature would leave a strip where the spawning is virtually non-existent, except for a few nearshore stations located in Arica and Antofagasta, it was possible to find anchoveta egg cores. Consequently, the distribution patterns of anchoveta larvae in northern Chile were altered as part of a strategy to cope with strong environmental changes. In agreement with Bertrand et al. (2004a), the anchoveta behaviour seems to be forced by bio-physical requirements as a result of adaptation to highly variable environmental conditions. We believe that events of this magnitude partially explain anchoveta population dynamics because of strong climate changes that occur at different time scales in the HCS, significantly altering the successive recruitment processes in northern Chile after a strong El Niño event.

\section{ACKNOWLedgMenTS}

The authors thank the crew from R/V 'Abate Molina' for logistical support provided in the field during oceanographic surveys in northern Chile, as part of the pelagic fishery exploration activities in this zone. Special thanks to Esteban Emparanza for the comments and suggestions regarding the manuscript. We also thank the anonymous reviewers for the contributions given to the manuscript. 


\section{LITERATURE CITED}

Alamo A \& M Bouchon. 1987. Changes in the food and feeding of the sardine (Sardinops sagax) during the years 19801984 off the Peruvian coast. Journal of Geophysical Research 92: 411-415.

Alheit J \& P Bernal. 1993. Effect of physical and biological changes on the biomass yield of the Humboldt Current Ecosystem. In: Sherman K, LM Alexander \& BD Gold (eds). Large marine ecosytems. Stress, mitigation and sustainability, pp. 53-68. American Association for the Advancement of Science, Washington.

Arcos DF, LA Cubillos \& S Núñez. 2001. The jack mackerel fishery and El Niño effects off Chile. In: McKinnell SM, RD Brodeur, K Hanawa, AB Hollowed, JJ Polovina \& CI Zhang (eds). Pacific climate variability and marine ecosystem impacts from the tropics to the Arctic. Progress in Oceanography 49: 597-617.

Arntz WE \& J Tarazona. 1990. Effects of El Niño 1982-1983 on benthos, fish and fisheries off the South American Pacific Coast. In: Glynn PW (ed). Global ecological consequences of the 1982-83 El Niño-Southern Oscillation. Elsevier Oceanography Series 52: 323-360. Elsevier, Amsterdam.

Bakun A. 2001. 'School-mix feedback': a different way to think about low frequency variability in large mobile fish populations. Progress in Oceanography 49: 485-511.

Barber RT \& FP Chavez. 1983. Biological consequences of El Niño. Science 22: 1203-1210.

Barber RT \& FP Chavez. 1986. Ocean variability in relation to living resources during the 1982-83 El Niño. Nature 319: 279-285.

Bertrand A, M Segura, M Gutierrez \& L Vasquez. 2004a. From small-scale habitat loopholes to decadal cycles: a habitat-based hypothesis explaining fluctuation in pelagic fish populations off Peru. Fish and Fisheries 5: 296-316.

Blanco JL, AC Thomas, ME Carr \& PT Strub. 2001. Seasonal climatology of hydrographic conditions in the upwelling region off northern Chile. Journal of Geophysical Research 106: 11451-11467.

Blanco JL, P Barría, J Castillo \& LP Atkinson. 2002. Response of anchovy (E. ringens) off northern Chile to the 1997-1999 El Niño-La Niña sequence. Investigaciones Marinas 30(1): 107-108.

Bosque-Sendra J. 1992. Sistemas de información geográfica, 451 pp. Ediciones Rialph, Madrid.

Bustos CA, MF Landaeta \& F Balbontín. 2008. Spawning and early nursery area of anchoveta Engraulis ringens Jenyns, 1842 in fjords of southern Chile. Revista de Biología Marina y Oceanografía 43(2): 381-389.

Carr ME. 2003. Simulation of carbon pathways in the planktonic ecosystem off Peru during the 1997-1998 El Niño and La Niña. Journal of Geophysical Research 108: 3380.
Carr ME, PT Strub, AC Thomas \& JL Blanco. 2002. Evolution of 1996-1999 La Nina and El Nino conditions off the western coast of South America: a remote sensing perspective. Journal of Geophysical Research 107: 3236.

Castillo J, MA Barbieri \& A González. 1996. Relationships between sea surface temperature, salinity, and pelagic fish distribution off northern Chile. ICES Journal of Marine Science 53: 139-146.

Castro LR, GR Salinas \& EH Hernández. 2000. Environmental influences on winter spawning of the anchoveta Engraulis ringens off Central Chile. Marine Ecology Progress Series 197: 247-258.

Castro LR, G Claramunt, MC Krautz, A Llanos-Rivera \& P Moreno. 2009. Egg trait variation in anchoveta Engraulis ringens: a maternal response to changing environmental conditions in contrasting spawning habitats. Marine Ecology Progress Series 381: 237-248.

Chavez FP, J Ryan, SE Lluch-Cota \& M Ñiquen. 2003. From anchovies to sardines and back: multidecadal change in the Pacific Ocean. Science 299(5604): 217-221.

Correa-Ramirez MA, S Hormazábal \& G Yuras. 2007. Mesoscale eddies and high chlorophyll concentrations off central Chile $\left(29^{\circ}-39^{\circ} \mathrm{S}\right)$. Geophysical Research Letters 34 : L12604: 1-5.

Cubillos LA, DF Arcos, M Canales \& D Bucarey. 2001. Seasonal growth of small pelagic fish off Talcahuano $\left(37^{\circ} \mathrm{S}-\right.$ $73^{\circ} \mathrm{W}$ ): A consequence of their reproductive strategy to seasonal upwelling? Aquatic Living Resources 14: 115-124.

Cubillos LA, J Paramo, P Ruiz, S Núñez \& A Sepúlveda. 2008. The spatial structure of the oceanic spawning of jack mackerel (Trachurus murphyi) off central Chile (19982001). Fisheries Research 90: 261-270.

Cushing DH. 1990. Plankton production and year class strength in fish populations: an update of the match/ mismatch hypothesis. Advances in Marine Biology 26: 250294.

Daneri G, V Dellarossa, R Quiñones, B Jacob, P Montero \& O Ulloa. 2000. Primary production and community respiration in the Humbold Current System off Chile and associated oceanic areas. Marine Ecology Progress Series 197: 41-49.

Escribano R \& P Hidalgo. 2000. Influence of El Niño and La Niña on the population dynamics of Calanus chilensis in the Humbold Current ecosystem of northern Chile. ICES Journal of Marine Science 57: 1867-1874.

Escribano R, G Daneri, L Farías, VA Gallardo, HE González, D Gutiérrez, CB Lange, CE Morales, O Pizarro, O Ulloa \& M Braun. 2004. Biological and chemical consequences of the 1997-1998 El Niño in the Chilean coastal upwelling system: a synthesis. Deep-Sea Research II 51: 2389-2411. 
Espino M. 1999. El Niño 1997-98: Su efecto sobre el ambiente y los recursos pesqueros en el Perú. Revista Peruana de Biología, Vol. Extraordinario: 97-109.

Espinoza P, V Blascovic, F Torriani \& I Navarro. 2000. Dieta de la anchoveta Engraulis ringens según intervalos de talla. Crucero BIC José Olaya Balandra y BIC Humboldt 9906. Informe, IMARPE 149: 41-48.

ESRI. 1996. ARCVIEW GIS, ArcView spatial analyst, 148 pp. Environmental Systems Research Institute, Redlands.

Fahrbach E, F Trillmich \& WE Arntz. 1991. The time sequence and magnitude of physical effects of the El Niño in the eastern Pacific. In: Trillmich F \& KA Ono (eds). Pinnipeds and El Niño responses to environmental stress, pp. 8-21. Springer, Berlin.

Fernández D, R Escribano \& P Hidalgo. 2002. Distribución de eufáusidos en el sistema de surgencia de la Península de Mejillones $\left(23^{\circ} \mathrm{S}\right)$ asociada a condiciones previas y durante El Niño 1997/98. Investigaciones Marinas 31: 56-72.

Giesecke R \& HE González. 2004. Feeding of Sagitta enflata and vertical distribution of chaetognaths in relation to low oxygen concentrations. Journal of Plankton Research 26(4): 475-486.

González HE, G Daneri, D Figueroa, JL Iriarte, N Lefevre, G Pizarro, R Quiñónez, M Sobarzo \& A Troncoso. 1998. Producción primaria y su destino en la trama trófica pelágica y océano profundo e intercambio océano-atmósfera de $\mathrm{CO}_{2}$ en la zona norte de la Corriente de Humboldt $\left(23^{\circ} \mathrm{S}\right)$ : Posibles efectos del evento El Niño 1997-1998 en Chile. Revista Chilena de Historia Natural 71: 429-458.

González HE, M Sobarzo, D Figueroa \& EM Nöthig. 2000. Composition, biomass and potential grazing impact of the crustacean and pelagic tunicates in the northern Humboldt Current area off Chile: differences between El Niño and non-El Niño years. Marine Ecology Progress Series 195: 201-220.

González HE, F Pages, M Sobarzo \& R Escribano. 2002. Effects of the 1997/98 El Niño on the oceanographic conditions and zooplankton community structure in the coastal upwelling system off northern Chile. Investigaciones Marinas 30: 112-114.

Hays WL. 1981. Statistics, 713 pp. Holt, Rinehart and Winston, New York.

Hernández EH \& LR Castro. 2000. Larval growth of the anchoveta Engraulis ringens during the winter spawning season off central Chile. Fishery Bulletin 98: 704-710.

Hernández-Miranda E \& FP Ojeda. 2006. Inter-annual variability in somatic growth rates and mortality of coastal fishes off central Chile: and ENSO driven process? Marine Biology 149: 925-936.
Hidalgo P \& R Escribano. 2001. Succession of pelagic-copepod species during the period 1996/1998 in northern Chile: the influence of the 1997-98 El Niño. Hydrobiologia 453: 153160.

Iriarte JL, G Pizarro, VA Troncoso \& M Sobarzo. 2000. Primary production and biomass size-fractioned phytoplankton off Antofagasta, Chile (23-24 $\left.{ }^{\circ} \mathrm{S}\right)$ during preEl Niño and El Niño 1997. Journal of Marine Systems 26: $37-51$.

Jongman RHG, CJF Ter Braak \& OFR van Tongeren. 1995. Data analysis in community and landscape ecology, 324 pp. Cambridge University Press, London.

Konchina YV. 1991. Trophic status of the Peruvian anchovy and sardine. Journal of Applied Ichthyology 31: 59-72.

Kong I, KC Tomicic \& LJ Zegers. 1985. Ichthyofauna associated to the 1982-1983 El Niño phenomenon in the northern of Chile. Investigación Pesquera, Chile 32: 215-224.

Kruskal WH \& WA Wallis. 1952. Use of ranks. Journal of the American Statistical Association 47: 583-621.

Landaeta MF, K Schrebler, CA Bustos, J Letelier \& F Balbontín. 2009. Temporal fluctuations of nearshore ichthyoplankton off Valparaíso, central Chile, during the ENSO cycle 1997-2000. Revista de Biología Marina y Oceanografía 44(3): 571-582.

Landaeta MF, PA Inostroza, A Ramirez, S Soto-Mendoza \& LR Castro. 2010. Distribution patterns, larval growth and hatch dates of early stages of the mote sculpin Normanichthys crockeri (Scorpaeniformes, Normanichthyidae) in the upwelling ecosystem off central Chile. Revista de Biología Marina y Oceanografía 45(S1): 575-588.

Llanos A, G Herrera \& P Bernal. 1996. Análisis del tamaño de las presas en la dieta de las larvas de cuatro clupeiformes en un área costera de Chile central. Scientia Marina 60(4): 435-442.

Llanos-Rivera A, G Herrera \& P Bernal. 2004. Food size selectivity and diet overlap in larvae of Clupeiform species from central Chile. Cahiers de Biologie Marine 45: 1-8.

Lluch-Belda D, DB Lluch-Cota \& SE Lluch-Cota. 2005. Changes in marine faunal distributions and ENSO events in the California Current. Fisheries Oceanography 14: 458-467.

Loeb V \& O Rojas. 1988. Interannual variation of ichthyoplankton composition and abundance ralations off northern Chile, 1964-83. Fishery Bulletin 86: 1-24.

Montero P, G Daneri, LA Cuevas, HE González, B Jacob, L Lizárraga \& E Menschel. 2007. Productivity cycles in the coastal upwelling area off Concepción: the importance of diatoms and bacterioplankton in the organic carbon flux. Progress in Oceanography 75: 518-530. 
Morales CE, M Braun, H Reyes, JL Blanco \& A Davies. 1996. Anchovy larval distribution in the coastal zone off northern Chile: the effect of low dissolved oxygen concentration and of a cold-warm sequence 1990-95. Investigaciones Marinas 24: 77-96.

Moreno CA, G Asencio, WE Duarte \& V Marín. 1998. Settlement of the muricid Concholepas concholepas (Brugiere) and its relationship with El Niño and coastal upwellings in southern Chile. Marine Ecology Progress Series 167: 171-175.

Orellana MC \& F Balbontín. 1983. Estudio comparativo de las larvas de clupeiformes de la costa de Chile. Revista de Biología Marina 19(1): 1-46.

Pavez MA, MF Landaeta, LR Castro \& W Schneider. 2010. Distribution of carnivorous gelatinous zooplankton in the upwelling zone off central Chile (austral spring 2001). Journal of Plankton Research 32(7): 1051-1065.

Perry JN, AM Liebhold \& MS Rosenberg. 2002. Illustrations and guidelines for selecting statistical methods for quantifying spatial pattern in ecological data. Ecography 25: 578-600.

Rodriguez-Graña L \& LR Castro. 2003. Ichthyoplankton distribution off the Peninsula de Mejillones, Chile $\left(23^{\circ} \mathrm{S}\right.$, $71^{\circ} \mathrm{W}$ ), under variable hydrographic conditions during the austral summer and winter of the 1997 El Niño. Hydrobiologia 501: 59-73.

Rojas PM. 2003. Variación estacional del ictioplancton en una zona de surgencia costera y factores ambientales asociados. Antofagasta-Chile. Ms thesis, Universidad Internacional de Andalucía, Sevilla, 80 pp.
Rose GA \& DW Kulka. 1999. Hyperaggregation of fish and fisheries: how catch-per-unit-effort increased as the northern cod (Gadus morhua) declined. Canadian Journal of Fisheries and Aquatic Sciences 56: 118-127.

Tarazona J, C Paredes, L Romero \& S Guzmán. 1988. La recolonización de las comunidades mítilicas en la costa central del Perú después de El Niño 1982-83. In: Salzwedell H \& A Landa (eds). Recursos y dinámica del ecosistema de afloramiento peruano. Boletín, Instituto del Mar de Perú, Vol. Extraordinario: 115-120.

Thomas AC, JL Blanco, ME Carr, PT Strub \& J Osses. 2001. Satellite-measured chlorophyll and temperature variability off northern Chile during the 1996-1998 La Niña and El Niño. Journal of Geophysical Research 106(C1): 899-915.

Ulloa O, R Escribano, S Hormazabal, RA Quiñones, M Ramos \& RR González. 2001. Evolution and biological effects of the 1997-98 El Niño in northern Chile. Geophysical Research Letters 28(8): 1591-1594.

Van der Lingen CD. 2002. Diet of sardine Sardinops sagax in the southern Benguela upwelling ecosystem. South African Journal of Marine Science 24: 301-316.

Zebiak S. 1999. El Niño and the science of climate prediction. Consequences 5(2): 3-15. 